\title{
BARREADO: SABOR, HISTÓRIA E CULTURA NO LITORAL PARANAENSE
}

\author{
Barreado: Flavour, History and Culture \\ in the Coast of Paraná
}

Maria Henriqueta Sperandio Garcia Gimenes*

\begin{abstract}
RESUMO
Este artigo se baseia na pesquisa realizada quando da elaboração da tese de doutorado em História pela Universidade Federal do Paraná, intitulada Cozinhando a tradição: festa, cultura e história no litoral paranaense, que compreendeu uma revisão bibliográfica sobre história do Paraná, com particular enfoque na alimentação, o levantamento de documentos em bibliotecas e arquivos públicos (incluindo folders, materiais de divulgação institucional e de restaurantes), além de quarenta e quatro entrevistas de História Oral. O Barreado, prato típico do litoral paranaense, é caracterizado como iguaria culinária e também como símbolo de sua região, tendo este artigo como foco o crescimento da oferta comercial desse prato nos municípios de Antonina, Morretes e Paranaguá.

Palavras-chave: barreado; história da alimentação; restaurantes, litoral paranaense.
\end{abstract}

\begin{abstract}
This article is based on the research made for the doctoral thesis in History for the Federal University of the State of Paraná entitled Cozinhando a tradição: festa, cultura e história no litoral paranaense (Cooking tradition: party, culture and history in the coast of Paraná), which comprises a bibliographic review of the history of Paraná, with particular emphasis on food, research of documents in libraries and public archives (including folders, institutional and restaurant marketing
\end{abstract}

Bacharel em Turismo, Mestre em Sociologia e Doutora em História pela Universidade Federal do Paraná. Professora do Curso de Turismo da Universidade Federal do Paraná. Endereço para correspondência: Rua Dr. Faivre, 600, ap. 61, Centro, Curitiba, Paraná, CEP 80060-140. Email: mariegimenes@gmail.com 
materials), as well as forty four Oral History interviews. The Barreado, a typical dish from Paraná coast, is taken herein both as a culinary delicacy and a symbol of its region. This article focuses on the growth of the commercial supply of this dish in the cities of Antonina, Morretes and Paranaguá.

Key-words: barreado; history of food; restaurants; coast of Paraná State.

\section{Introdução}

O fenômeno da alimentação humana permite desvendar valores, significados e representações que muito dizem sobre os próprios grupos sociais. Por consequência, tornou-se ao longo dos tempos objeto de áreas de conhecimento diversas, tais como a Nutrição, a Antropologia e a História, sendo esta última uma disciplina de convergência, uma zona de fronteira a partir da qual conhecimentos inter e multidisciplinares se organizam com base em procedimentos metodológicos e discussões teóricas que buscam compreender em perspectiva de tempo e espaço manifestações e processos relacionados à alimentação humana. Para o historiador Carlos Roberto Antunes dos Santos (1997, p. 155) os estudos inter e multidisciplinares são de grande pertinência no âmbito da História da Alimentação, no sentido de possibilitar pensar o objeto no contexto mais amplo possível, "combinando variáveis históricas e dialogando constantemente com outras disciplinas". E, como observa o historiador Henrique Carneiro:

O costume alimentar pode revelar de uma civilização desde a sua eficiência produtiva e reprodutiva, na obtenção, conservação e transporte dos gêneros de primeira necessidade e os de luxo, até a natureza de suas representações políticas, religiosas e estéticas. Os critérios morais, a organização da vida cotidiana, o sistema de parentesco, os tabus religiosos, entre outros aspectos, podem estar relacionados com os costumes alimentares (CARNEIRO, 2005, p. 72).

Assim, considerando que o gosto alimentar reflete tanto um exercício sensorial, mas também uma forma de apropriação simbólica 
(BOURDIEU, 1983), verifica-se que o estudo da história da alimentação, mais do que constatar mudanças e inovações, identifica também constâncias alimentares que tornaram-se tradição, agregando conteúdos capazes de criar e reforçar sentimentos de pertencimento. Ganham relevo nessa perspectiva as tradições culinárias, aqui compreendidas como saberes-fazeres "transmitidos entre gerações e cujos significados, dentro da própria lógica da dinâmica cultural, podem ser alterados ou adaptados, sem que se percam, no entanto, determinadas características e conteúdos que garantam seu reconhecimento como tal" (GIMENES, 2008, p. 54).

Neste contexto, o preparo e consumo de uma iguaria podem representar um exercício identitário (MACIEL, 2004), envolvendo muitas vezes não apenas a repetição da receita e a fidelidade aos ingredientes, mas também a reprodução das condições em que a iguaria era preparada. Tem-se, então, mais do que algo a ser degustado, a construção de um alimento-memória, capaz de conectar o indivíduo a um passado valorizado ou que se deseja recuperar (SANTOS, 2004).

Dada a heterogeneidade de sua paisagem geográfica e humana, o Brasil encerra em seu território uma diversidade gastronômica incomparável. Em todos os estados brasileiros há práticas alimentares enraizadas, que terminam por se cristalizar nos chamados "pratos típicos". Tais pratos se fixam como símbolos de suas localidades e ganham inclusive notoriedade nacional, como é o caso do acarajé (BA), da torta capixaba (ES) e do pão de queijo (MG). No caso do Paraná, evidencia-se o Barreado como o principal exemplo deste processo.

Preparado no litoral paranaense, com a origem envolta em lacunas e contradições, o Barreado é uma iguaria feita à base de carne bovina cozida exaustivamente com condimentos, utilizando tradicionalmente como recipiente uma panela de barro hermeticamente fechada com goma de farinha de mandioca - técnica que inclusive batizou o prato. Tem como características marcantes a textura e a apresentação da carne, praticamente desmanchando, que é servida com farinha de mandioca e banana. Sua receita, disseminada por meio da tradição oral, possui variações principalmente no que se refere aos temperos adicionados à carne e à forma de preparo, variedade resultante da apropriação coletiva que contribuiu para a perpetuação desta tradição.

A importância do prato, entretanto, não se encerra na peculiaridade de seu preparo nem em seu sabor. Mais do que uma iguaria gastronômica, o 
Barreado é uma manifestação intimamente ligada a outras práticas culturais litorâneas, presente na mesa dos autóctones nos domingos, em casamentos, batizados e aniversários, bem como nas festas comunitárias e religiosas, vinculada até hoje aos festejos do Carnaval e ao Fandango. Símbolo de festa e fartura para as comunidades do litoral, o Barreado extrapolou o âmbito doméstico e alcançou a esfera comercial, sendo atualmente servido e degustado em larga escala em restaurantes dos municípios de Antonina, Morretes e Paranaguá.

Devido à importância histórica, cultural e turística do prato, foi concebida a tese de doutoramento em História, orientada pelo professor e historiador Carlos Roberto Antunes dos Santos, intitulada Cozinhando a tradição: festa, cultura e história no litoral paranaense (GIMENES, 2008). Durante a realização da pesquisa, efetuou-se uma revisão de bibliografia e uma pesquisa empírica, pautada na análise de fontes impressas e orais. Foram arrolados, fichados e analisados diversos artigos e documentos que tratam do Barreado, do desenvolvimento do litoral paranaense e da evolução da atividade turística no Estado do Paraná. Neste sentido, a consulta aos arquivos da Biblioteca Pública do Paraná, em Curitiba, da Biblioteca Pública Municipal Comendador Theobaldo Pereira, em Antonina, da Biblioteca Pública Municipal José Gonçalves de Moraes, em Morretes, da Biblioteca Pública Municipal Leôncio Correia, em Paranaguá, e aos Arquivos da Paraná Turismo foram essenciais.

As entrevistas foram conduzidas segundo as premissas da História Oral $^{1}$, por meio de entrevistas semiestruturadas, englobando os seguintes sujeitos: cozinheiros(as) tradicionais; gerentes e proprietários de restaurantes; cozinheiros responsáveis pelo preparo do Barreado e pessoas ligadas ao desenvolvimento da atividade turística no Estado e nos municípios. Aqui foram considerados como cozinheiros(as) tradicionais aqueles que preparam

1 A História Oral, que é caracterizada por Jorge Eduardo Aceves Lozano (2002, p. 17) como um procedimento que visa à "constituição de novas fontes para a pesquisa histórica, com base nos depoimentos orais colhidos sistematicamente em pesquisas específicas, sob métodos, problemas e pressupostos teóricos explícitos", ganhou maior destaque e novos adeptos. Dentre suas especificidades, que demandam procedimentos e cuidados específicos por parte do pesquisador, Danièle Voldman (2002, p. 37) aponta dois aspectos que podem ser considerados, simultaneamente, pontos fortes e fracos: em primeiro lugar, a interação entre o entrevistado e o entrevistador, pois o depoimento consiste em um momento em que "duas subjetividades imediatas se conjugam, tanto para esclarecer quanto para confundir as pistas". Em segundo lugar, consta o fato de que o depoimento oral depende da memória do indivíduo, que deve ser estimulada pelo entrevistador. 
o prato em suas residências de forma cotidiana, sem intuito comercial. No total foram entrevistadas quarenta e quatro pessoas, compondo uma amostra de caráter qualitativo não probabilístico.

Este artigo, portanto, baseia-se nas informações coletadas para a elaboração da supracitada tese e tem como objetivo caracterizar o Barreado enquanto iguaria culinária, mas também como símbolo de sua região, a partir da apresentação de dados referentes ao crescimento da oferta comercial dessa iguaria nos municípios de Antonina, Morretes e Paranaguá.

\section{Barreado, o prato}

A origem do Barreado é até hoje motivo de debate acirrado entre capelistas (antoninenses), morretianos e parnanguaras, que, ao reivindicarem para si essa paternidade, terminam por costurar a origem defendida aos aspectos históricos marcantes para seus municípios, dando um caráter identitário à questão. A partir das versões coletadas, há consenso de que o Barreado é preparado e degustado há centenas de anos no litoral paranaense, especialmente em Antonina, Guaraqueçaba, Guaratuba, Morretes e Paranaguá. Em algumas versões, a influência lusitana é especificada como "herança açoriana", por conta da utilização de panelas de barro e o cozimento exaustivo da carne com outros ingredientes (no caso açoriano, em fogões improvisados nos vapores vulcânicos; no caso litorâneo, em valas aquecidas com brasas), dentre outras características que aproximam o Barreado da alcatra, prato típico das Ilhas dos Açores.

Bastante polêmica é a associação da origem do Barreado com o tropeirismo ${ }^{2}$, citada por alguns dos entrevistados e por algumas fontes

2 Baseado no transporte de mercadorias, o tropeirismo ganhou destaque a partir de 1731, quando a exportação de animais do extremo sul para as regiões centrais do Brasil tornou-se um negócio altamente rentável, até se esgotar em 1870, quando a construção das estradas de ferro em São Paulo desvalorizou o muar como meio de transporte. Nas palavras de Balhana, Machado e Westphalen, o tropeirismo consistia no negócio de "ir comprar as muladas no Rio Grande, no Uruguai, na Argentina, conduzi-las em tropas, numa caminhada de três meses pela estrada do Viamão, inverná-las por alguns meses nos campos do Paraná, e vendê-las na grande feira anual de Sorocaba, onde vinham comprá-las paulistas, mineiros e fluminenses" (BALHANA; MACHADO; WESTPHALEN, 1969, p. 65). 
escritas. Os ingredientes utilizados pelos tropeiros (a carne preferida era o charque, pela facilidade de transporte e conservação, e não a carne verde, usada no Barreado), bem como o longo tempo necessário para o cozimento adequado do prato e sua durabilidade depois de pronto, além da própria dificuldade em transportar os panelões de barro necessários, são alguns dos vários elementos que apontam para a improbabilidade dessa hipótese.

A versão mais aceita foi publicada pelo professor parnanguara Manoel Viana em 1976, que relata que os primeiros filhos de portugueses com índios conheceram na casa de seus patrões o guisado português e resolveram reproduzi-lo em suas residências, utilizando carne de segunda, que era mais barata (VIANA, 1976). Após várias adaptações, foi incorporado o hábito de vedar a panela com uma mistura de farinha de mandioca e água, técnica que leva o nome de "barrear" (que, inclusive, batiza o prato).

Entretanto, se sua verdadeira origem permanece na penumbra, evidente é a ligação - que perdura até a atualidade - do Barreado com os festejos carnavalescos. Tal ligação remonta aos tempos do Entrudo ${ }^{3}$, o precursor do Carnaval, e parece ter sido fundamental para a longevidade do prato:

Durante os três dias de Entrudo, o caboclo do litoral não fazia outra coisa a não ser dançar Fandango e comer. O alimento desses três dias para quantos amanheciam exaustos, sem energias para preparar o almoço, era o Barreado, cujo cozimento resistia às 72 horas de folia. (BARREADO..., 1963, p. 31).

O Barreado era (e ainda é) considerado um prato "forte", capaz de repor as energias, além de exigir poucos acompanhamentos (para os mais tradicionalistas, a farinha de mandioca e a banana são suficientes) e ter seu sabor preservado mesmo quando requentado. Outro aspecto que contribuiu para a ampliação de sua degustação para além dos limites carnavalescos foi

3 O folclorista Alexandre José de Melo Morais Filho (1979) descreve o Entrudo (do latim introitu, introdução) como um jogo herdado de Portugal que acontecia no Brasil inteiro três dias antes do início da Quaresma. Sua denominação fazia referência justamente ao período que introduz a Quaresma (do latim quadragésima), data que marca o início dos quarenta dias que antecedem à Páscoa. O Entrudo caracterizava-se então como três dias de excesso que antecipavam um período de penitência e constrição, que foi introduzido no país no século XVII e ganhou força no século XVIII. Muitas vezes significava uma brincadeira violenta que tomava as ruas, com as pessoas atirando umas nas outras laranjas e limões de cheiro, bacias d'água, polvilho e até mesmo terra. 
sua forte associação ao fandango, uma manifestação cultural popular que reúne dança e música, praticado há centenas de anos no litoral sul de São Paulo e no litoral norte do Paraná, principalmente nas cidades de Cananeia (SP), Iguape (SP), Morretes (PR), Paranaguá (PR) e Guaraqueçaba (PR).

$\mathrm{O}$ fandango tem suas danças classificadas em valsadas ou batidas, bailadas em pares, com os homens batendo palmas e tamanqueando. Juntamente com o barulho dos tamancos têm-se a viola e a rabeca, geralmente feitas de caixeta e confeccionadas manualmente pelos próprios fandangueiros, além dos instrumentos de percussão como o adufo (ou adufe) e o pandeiro (GRAMANI; CORREAA, 2006). Dançado exaustivamente no carnaval, o fandango também era comum durante os mutirões ou pixirões ${ }^{4}$ para o preparo da terra, para colheita ou ainda para a "bateção do arroz", ocasiões nas quais se reuniam amigos e vizinhos para ajudar e, em troca, se oferecia o Barreado e um baile de fandango. "Nas regiões rurais, as festas de fandango estavam vinculadas ao calendário agrícola de subsistência, como o plantio e a colheita, ocasiões em que o dono da lavoura convocava um mutirão e, ao final do dia, oferecia um baile de fandango" (RANDO, 2003, p.12).

A receita do Barreado provavelmente foi alterada ao longo dos anos, adaptada aos produtos e à tecnologia disponível e também ao paladar dos comensais, gerando em cada família uma versão do prato, numa lógica de apropriação coletiva que permite a existência do Barreado da dona Iza, da dona Glória e do senhor Joaquim, dentre tantos outros, sempre tendo como ingredientes indispensáveis a carne bovina, o toucinho (ou o bacon) e o cominho.

A carne bovina utilizada no Barreado é a de segunda, aspecto inicialmente ligado às limitações financeiras dos caboclos do litoral, mas que encontra também explicação culinária, na boa resistência das carnes mais duras ao cozimento prolongado. Dentre as cozinheiras tradicionais, a resposta soa quase que uníssona: Barreado se faz com carne de segunda, pois esta é mais saborosa!

4 "Mutirão, pixirão, pixirunga, mitirão, multirão, mutirom, pixirom, puxirão, ademão são palavras usadas para designar uma forma de trabalho coletivo, comum em toda a região, onde os vizinhos se reuniam em prol da realização de uma empreitada. Um mutirão poderia ser realizado, dentre outras coisas, para a derrubada da mata, para a limpeza de uma trilha, para o plantio e a colheita de arroz, mandioca, milho, feijão e outros alimentos, para puxada ou varação de canoa" (GRAMANI; CORRÊA, 2006, p. 28). 
Os cortes mais usados, segundo os levantamentos realizados, são patinho, peito, paleta, lombo agulha, coxão-mole e alcatra (apesar destas duas últimas não serem consideradas carnes de segunda). Recomenda-se, em geral, usar qualquer carne de segunda magra, assim como o coxão-duro, o granito, a posta branca, o matambre e a posta vermelha. A gordura do porco também é indispensável à receita e aparece como toucinho (preferido pelos mais tradicionalistas, é o corte fresco de carne suína) ou bacon (o mesmo corte, só que defumado, adotado mais recentemente).

No que tange aos temperos adicionados, o cominho é um elemento essencial. Especiaria trazida para o Brasil pelos portugueses, possui um sabor bastante característico, entre a pimenta e o anis, e é mais utilizado no nordeste brasileiro, basicamente para o preparo de peixes e frutos do mar (NEPOMUCENO, 2005). O cominho é citado por muitos dos entrevistados como sendo o segredo do bom Barreado. Outro tempero importante é o louro, utilizado por conta de seu aroma característico e também por suas funções medicinais, principalmente digestivas. A união do cominho com o louro é a responsável pelo aroma inconfundível exalado das panelas durante o cozimento.

Outros ingredientes bastante comuns nas receitas do prato são a cebola, o alho, a pimenta-do-reino, além do sal, trazido pelos colonizadores europeus para o Brasil e rapidamente assimilado nas novas terras. O cheiro-verde, combinação de salsinha e cebolinha, é considerado por muitos uma inovação, bastante aceita entre os cozinheiros. A pimenta malagueta ou vermelha, por sua vez, aparece nas receitas tanto como ingrediente como quanto acompanhamento indispensável durante a degustação.

Mesmo diante destas variações, alguns ingredientes como a água, o vinagre e o tomate são bastante polêmicos, mas aparecem em várias receitas, inclusive em algumas divulgações oficiais. Para os tradicionalistas, a carne deve ser fervida e refervida em seu próprio suco, sem que seja adicionada água, pois muita água tiraria a consistência do caldo, o que impossibilitaria um pirão saboroso.

Há maior resistência, porém, à utilização do tomate, do vinagre ou de outro elemento ácido, sob a alegação de que tais ingredientes modificam o sabor da carne e estragam o Barreado. O tomate, apesar de ser produzido na região, não é por natureza um produto compatível com as características climáticas do litoral paranaense (CAMARGO FILHO et al., 1994). Deve-se 
considerar ainda que há indícios de que seu cultivo tenha se desenvolvido no litoral com a chegada dos imigrantes japoneses na região, ocorrida apenas no século XX, o que leva à conclusão de que sua inclusão na receita constitui muito mais uma "modernidade" do que uma tradição.

A panela de barro é um elemento muito tradicional, sendo apontado como o melhor recipiente para preservar o gosto dos alimentos. Os ingredientes são refogados ou dispostos em camadas, a panela é levada ao fogo e, na sequência, lacrada com uma mistura geralmente feita à base de água (fria ou fervente, dependendo da receita) e farinha de mandioca, embora variações compostas por farinha de trigo e cinzas de fogão a lenha sejam bastante populares. Usam-se também folhas de bananeira (a folha, ao ser passada no fogo, fica maleável como o papel, mas mantém sua resistência) cortadas de acordo com a abertura da panela, onde são amarradas e ajudam na vedação. Na sequência, a tampa é colocada e procede-se ao barreamento. $\mathrm{O}$ resultado é a criação de um dispositivo primitivo, equivalente ao de uma panela de pressão, com o objetivo de manter a pressão e a umidade da carne em um ponto favorável ao seu cozimento, devendo ser realizada com bastante precisão e mantida ao longo de todo o processo.

É relevante mencionar, ainda, as histórias ouvidas dos antigos moradores, que relatam o Barreado sendo cozido em uma panela enterrada, criando uma espécie de fogão artesanal, segundo uma técnica chamada biaribi. De acordo com Cascudo (2004), a técnica já era dominada tanto por ameríndios quanto por africanos desde o século XVII. Há ainda a utilização dos fogões a lenha, também considerada tradicional, e de forma mais contemporânea a popularização do fogão a gás no preparo do prato.

Tradicionalmente o tempo de preparo do Barreado é de aproximadamente vinte e quatro horas. Contudo, verificou-se que os Barreados contemporâneos são preparados mais rapidamente, provavelmente por conta da estabilidade e da potência da chama dos fogões modernos, bem como pela substituição da panela de barro pela de alumínio.

O serviço do Barreado também tem as suas especificidades, que fazem parte de seu folclore. A abertura da panela requer prática, pedindo cuidados na remoção da massa barreada e da folha da bananeira. É precedida por um sinal sonoro (espocar de foguetes ou tocar de um sino), tanto em Antonina, Morretes e Paranaguá. Tal hábito remonta a centenas de anos, sendo associado também a celebrações religiosas e comunitárias. Como 
acompanhamento da iguaria não se pode deixar de mencionar a farinha de mandioca, a banana e a cachaça (principalmente a de banana), bem como o arroz branco, onipresente na mesa dos brasileiros, também incorporado à degustação do prato.

Claramente, portanto, o Barreado é uma manifestação ligada diretamente à cultura do litoral paranaense e uma iguaria de sabor e preparo bastante característicos, presente em festas públicas e privadas, nas residências e também nos restaurantes, ao alcance de turistas e autóctones. E é justamente esta oferta comercial, que estabelece o Barreado como atrativo turístico de Antonina, Morretes e Paranaguá, que será tratada a seguir.

\section{Barreado: a construção do símbolo}

A passagem do Barreado do âmbito doméstico para o comercial provocou, ao longo dos tempos, a incorporação de uma série de inovações, seja diante da necessidade de ofertá-lo em escala comercial, garantindo suas condições higiênico-sanitárias, seja pela necessidade de facilitar e aumentar a produção da iguaria. O fato é que, embora o Barreado mantenha seu "uso privado", é no âmbito comercial que ganha notoriedade e se torna um atrativo turístico, caracterizando-se, por consequência, como um fator de desenvolvimento.

Observou-se que a moderna tradição do Barreado, entendida aqui como a maneira com que a iguaria é preparada e servida comercialmente na contemporaneidade, envolvendo uma série de permanências e inovações que se conjugam criando novas tradições, começou a ser desenhada em Morretes em meados de 1940 e ganhou força ao longo das décadas seguintes. Analisa-se aqui, portanto, como se deu a construção da oferta do prato, tomando como linha mestra a oferta comercial da iguaria nos municípios de Antonina, Morretes e Paranaguá e a atuação dos empresários que participaram ativamente desse processo. 


\subsection{OS PRIMEIROS ESTABELECIMENTOS}

A tradição moderna do Barreado não pode ser contada sem que sejam mencionados três personagens: o português Antonio Alpendre, residente em Morretes, a capelista Ieda Siedschlag e o morretiano descendente de italianos Honílson Fabris Madalozo. Antonio Alpendre fundou o Hotel Nhundiaquara, que inaugurou a oferta comercial do Barreado em meados da década de 1940. Dona Ieda foi uma das promotoras do resgate do Barreado no final da década de 1960 em Antonina e uma das responsáveis pela fama do prato na década seguinte. Honílson Fabris Madalozo fundou o Restaurante Madalozo, primeiro restaurante "de rua" que incluiu o Barreado em seu cardápio, responsável também por algumas inovações hoje havidas como "tradicionais".

Pioneiro da oferta comercial do Barreado, Antonio Alpendre chegou ao Brasil em 1902 e estabeleceu-se em Antonina, atuando como comerciante. Primeiro manteve um bar, antes de entrar no ramo da hotelaria. Na década de 1920, casou-se com Amália Martinha Alpendre, capelista, com quem teve seis filhos, sendo a mais velha Maria da Glória Alpendre Silveira, nascida em 1927 e que até hoje está à frente do hotel e restaurante da família. A primeira sede do hotel ficava na hoje chamada Rua XV, mas problemas com o endereço, como o excesso de pernilongos e as condições de tráfego, geraram complicações para o Hotel Central, motivando o proprietário a procurar um novo endereço.

O casarão que abriga a atual sede do Hotel Nhundiaquara (o nome foi adotado na mudança) é uma construção do século XVIII, a mais antiga de Morretes e a primeira a receber água encanada, em 1934. Tornou-se uma imagem emblemática do município, comum em cartões postais e em divulgações daquela cidade. Em 1945, o casarão, que já havia sido residência, cassino, escola, fábrica de meias, centro espírita e sede da repartição geral dos telégrafos (o primeiro telégrafo da cidade) foi inaugurado como hotel. O novo empreendimento teve dias de grande prosperidade, motivados pela dificuldade de acesso a Paranaguá e às praias e se mantinha, recebendo então diversas famílias de Curitiba e também de municípios diversos do Paraná, as quais se hospedavam em Morretes por conta do clima agradável ou que ali permaneciam aguardando melhores condições da estrada para descerem até os balneários. 
Dona Maria da Glória recorda que incluíram o Barreado no cardápio por insistência de um familiar, ainda quando seu pai era vivo, porém com certa desconfiança, devido ao fato de que todos de Morretes conheciam o Barreado: era um prato "das casas", que poderia não agradar aos visitantes. A entrevistada não se lembra do ano exato em que o Barreado foi incluído no cardápio; recorda apenas que isto ocorreu já no Hotel Nhundiaquara e que foi antes de se casar, o que localiza o período entre 1945 e 1950. Sua memória, entretanto, é bastante viva ao relembrar do sucesso alcançado pelo prato. Segundo ela, para surpresa de todos, o Barreado foi tão bem aceito que passaram até mesmo a atender pedidos para servi-lo fora do hotel.

Em 1947, com a morte do sr. Antonio Alpendre, dona Amália Martinha assumiu o hotel juntamente com suas filhas. A demanda turística de Morretes nesta época era pequena e se desenvolvia lentamente, sem investimentos ou uma proposta de atração e permanência de visitantes, e se resumia às pessoas que trabalhavam na cidade (gerentes, comerciantes, médicos, juízes, professores etc.) mas que residiam em outros lugares e aos turistas que se destinavam às praias, ou que procuravam na cidade um clima mais agradável do que o de Curitiba. Em 1963, com o falecimento da mãe, dona Maria da Glória assumiu o Hotel Nhundiaquara.

Em Morretes, no mesmo ano, outro personagem fundamental para a divulgação e comercialização do Barreado entrou no ramo da alimentação: Honílson Fabris Madalozo, alfaiate, neto de imigrantes italianos, nascido em 1929, casado com dona Izanete Madalozo, nascida em 1938, com quem teve três filhos. Residente em Morretes, insatisfeito com o furto de sua alfaiataria, resolveu mudar de ramo e abriu um bar, chamado Bar e Snooker Madalozo. Testemunha da trajetória do marido, já falecido, dona Izanete é neta de italianos que se estabeleceram na cidade de Morretes com um engenho de aguardente e um moinho de arroz. O Bar e Snooker Madalozo começou servindo café da manhã para caminhoneiros e viajantes e, algum tempo depois, incorporou a culinária italiana no cardápio. O Barreado foi incorporado posteriormente, apenas no início da década de 1970.

Em Antonina, no final da década de 1970, dona Ieda Siedschlag, capelista nascida em 1936, começou a perceber que a tradição do preparo do Barreado estava enfraquecendo, na medida em que as famílias gradativamente deixavam de prepará-lo. "Esse Barreado tradicional era feito há muitos anos em Antonina, e eles faziam nas residências porque a família 
vinha para o Carnaval em Antonina e queria comer o Barreado" (SIEDSCHLAG, 2008). Dona Ieda conta que a ideia de recuperar a tradição do Barreado partiu dela e de sua amiga, a antoninense Neréa Gomes Moreira de Moraes Sarmento, e foi implantada no Clube Náutico de Antonina. Ela esteve à frente do bar do clube durante um período e lá preparava Barreado, feijoada, peixadas, um pouco de tudo.

Para divulgar o Barreado, dona Ieda entrou em contato com alguns colunistas sociais, como seu amigo Dino Almeida, que na época já escrevia para o jornal Gazeta do Povo, avisando que o Clube Náutico estaria aceitando encomendas de Barreado para o final de semana. O movimento do primeiro final de semana e dos seguintes foi intenso. Dona Ieda recorda que a amiga Neréa Sarmento tocava o disco do Hino de Antonina e soltava foguetes no momento da abertura da panela, reproduzindo as tradições antoninenses que estavam sendo deixadas de lado. O Barreado no Clube Náutico nasceu então como uma proposta efetiva de resgate não apenas do prato, mas também de outras tradições que lhe eram vinculadas. Segundo Dona Ieda, “[...] eu sempre dizia: 'Gente, vamos fazer o verdadeiro Barreado porque é o nome de Antonina que vai ser elevado"' (SIEDSCHLAG, 2008).

Com a inauguração da pista simples da BR-277 pelo então presidente Costa e Silva em 1969, o trânsito interno da cidade de Morretes foi melhorado, bem como o acesso às praias. Mas o comércio local, movimentado por conta dos passantes, sentiu a diminuição do fluxo de carros e caminhões. Deixando de ser um ponto de passagem praticamente obrigatório para os que se deslocavam para Paranaguá e para os balneários, a cidade precisava agora estabelecer novos atrativos e estratégias para que seus fluxos de visitantes fossem mantidos, tanto do ponto de vista do turismo quanto do comércio em geral.

Paranaguá, Antonina e Morretes passaram, a partir desta época, a serem mais valorizadas por conta de seus aspectos históricos, sendo que o patrimônio cultural no sentido amplo (abrangendo a culinária e os folguedos populares, por exemplo) ficava ainda restrito aos festejos carnavalescos. $\mathrm{O}$ Barreado, quando divulgado, era associado ao litoral como um todo e ao Carnaval, sem que houvesse uma iniciativa de sinalizar a oferta comercial que começava a ser construída. 


\subsection{A OFERTADO BARREADO NAS DÉCADAS DE 1970 E 1980}

Em 1971 a oferta do Barreado recebeu um reforço importantíssimo: foi a partir deste ano que o Bar e Snooker Madalozo, em Morretes, começou a servir refeições em seu cardápio, inicialmente comida italiana e, posteriormente, o Barreado. Com a introdução do serviço de refeições, o estabelecimento passou a ser chamado de Restaurante Madalozo. A demanda de final de semana crescia a olhos vistos, gerando inclusive alterações na própria estrutura física do estabelecimento, visando à melhor acomodação dos comensais: "[...] vinha muita gente de Curitiba e em pouco tempo a clientela do restaurante aos domingos passou a ser 90\% de Curitiba" (LAFITTE, 2008).

Em relação a Antonina, o Barreado continuava sendo servido apenas no Clube Náutico, pois dona Ieda, apesar da insistência dos clientes, ainda não estava convencida de que deveria abrir um restaurante. O ano de 1972, porém, foi um ano bastante complicado para a economia capelista, pois as Indústrias Matarazzo ${ }^{5}$ encerraram suas atividades, o que reduziu em muito as alternativas de emprego e renda para os moradores da localidade, criando um panorama que mesmo o início das atividades da Fergupar - Ferro Gusa Paraná Ltda. - não conseguiu reverter. Entretanto, a crise não afetou a procura pelo Barreado aos domingos no Clube, tendo em vista que os comensais eram, em sua maioria, visitantes.

A oferta do Barreado em Antonina se concentrava então no Clube Náutico, panorama alterado no ano seguinte, com a abertura do restaurante da dona Ieda. Em 1. ${ }^{\circ}$ de maio de 1974, dona Ieda Siedschlag, incentivada pelos frequentadores do Clube Náutico de Antonina, abriu seu próprio restaurante, aproveitando uma casa de hóspedes que estava desocupada. Dona Ieda recorda que abriu seu estabelecimento com uma capacidade restrita e uma pequena equipe de apoio, com dez mesas e quarenta cadeiras, duas senhoras que ajudavam na limpeza da carne, seu irmão e um garçom, seu primo. O restaurante, que se chamava CACOAN - Campo de Concentração

5 Em 1917, a Indústria Matarazzo se estabeleceu em Antonina, em uma iniciativa de expansão para além dos domínios do Estado de São Paulo, buscando extrapolar o âmbito comercial e ingressar na área de produção de bens. Foram instalados um moinho para fornecer farinha de trigo para os mercados do sul do país, além de casas para seus funcionários (vila de operários) e uma escola, revigorando a economia local. 
dos Amigos de Antonina (mas que era chamado basicamente de Restaurante da Ieda ou de Barreado da Ieda) -, rapidamente fez sucesso, reunindo novos e antigos clientes.

Retomando a realidade morretense, em 1976, diante da grande procura pelo restaurante nos finais de semana, o senhor Honílson Madalozo começou a planejar a expansão de seu estabelecimento. Segundo Tânia, "nós tínhamos fila de espera aos domingos, quando na realidade começou a ideia de construir aqui [atual sede], porque lá se tornou pequeno, quando tinha aquela fila de espera" (LAFITTE, 2008). Assim, a intensa procura pelo prato nos finais de semana e feriados incentivou a família Madalozo a abrir uma nova casa, maior, construída às margens do Rio Nhundiaquara.

O Restaurante Madalozo foi o primeiro a se instalar nas margens do rio, hoje uma região cobiçadíssima pelos demais empresários do ramo, que reconhecem na vista para o Nhundiaquara um diferencial que agrada - e atrai - a clientela. Dona Izanete relembra como era o local antes da construção: não havia restaurantes, apenas algumas casas e algumas empresas exploravam o local retirando areia para ser vendida para construções. A área comercial da cidade ficava então concentrada na Rua XV de Novembro. O terreno escolhido era da familia de dona Izanete, que o recebeu da tia que a criou (dona Izanete ficou órfã com apenas um ano e oito meses). A escolha do local, contudo, não foi planejada: outro terreno estava sendo negociado pelo senhor Madalozo, mas o negócio não foi fechado.

Em agosto de 1977 foi publicada uma reportagem da Gazeta do Povo intitulada Litoral e Barreado (LITORAL e..., 1977, p. 10) citando os restaurantes que serviam os pratos típicos do litoral, especialmente o Barreado. Dos restaurantes capelistas especializados em Barreado foram citados o Restaurante do Clube Náutico (à la carte diversificado e frutos do mar, com Barreado nos finais de semana e sob encomenda durante a semana) e o Restaurante Cacoan, que era ressaltado por conta de sua simpática proprietária. Dos restaurantes morretenses, apenas o Restaurante do Hotel Nhundiaquara (peixe e frutos do mar, churrasco e Barreado) e o Restaurante Madalozo são citados.

O texto indicava ainda um aumento pela procura e pela oferta da iguaria em Morretes: "como a onda está alta - e foi por nós constatada, todos os restaurantes e bares da rua principal, a XV de Novembro, tinham anunciado na porta 'Hoje Barreado', e podemos informar que no conhecido 
Bar Barril o preço é Cr\$ 35,00" (LITORAL e..., 1977). Infelizmente tal reportagem, apesar de apontar o aumento do serviço do Barreado na cidade, não indica o nome dos demais estabelecimentos que o serviam, da mesma forma que não foi possível identificar, por meio das fontes orais, outros estabelecimentos dedicados ao Barreado ou ainda ter maiores informações sobre o Bar Barril. Finalizando, o artigo, que possui um caráter informativo bastante evidente (apresentando os cardápios de forma resumida, os preços, os horários de atendimento), conclamava:

É chegada a hora de você, que é paranaense e nunca provou o Barreado - o único prato típico de nosso estado; ou você que não nasceu mas vive aqui e nunca provou o Barreado; ou você que já provou e há muito tempo não repete: enfim, é chegada a hora de entrar na onda, ir a Morretes ou Antonina e fazer jus a um gostoso Barreado (LITORAL e..., 1977, p.10).

Pela maneira com que as publicações passam a abordar o Barreado, verifica-se que ele paulatinamente deixa de ser associado às residências e ao período carnavalesco, passa a ser empregado como um atrativo que impulsiona deslocamentos e que pode ser degustado ao longo de todo o ano nos restaurantes que o preparam e o servem. Em Morretes, em primeiro de agosto de 1978, a nova sede do Restaurante Madalozo foi inaugurada, com capacidade para 250 lugares e servindo o Barreado e a comida italiana. Devido à predominância de pedidos do Barreado e de frutos do mar, nos anos seguintes a culinária italiana foi aos poucos sendo excluída do cardápio. Anos depois, o Restaurante Madalozo introduziu uma nova opção de refeição que foi muito bem aceita pelos clientes e também copiada por praticamente todos os restaurantes da cidade e da vizinha Antonina: o combinado de Barreado com frutos do mar, servido no sistema de rodízio.

No início da década de 1980, o Barreado era degustado nas residências de Antonina, Morretes e Paranaguá principalmente no período carnavalesco e em festas familiares, religiosas e comunitárias. Para aqueles que não possuíam familiares no litoral, desconheciam a receita ou ainda não dominavam a forma de preparo, a abertura de restaurantes que serviam o Barreado ampliou enormemente o acesso à iguaria. O Restaurante do Hotel Nhundiaquara, o Restaurante da Ieda, o Restaurante Madalozo e o Restau- 
rante Danúbio Azul ${ }^{6}$ iniciam os anos oitenta funcionando em pleno ritmo e conquistando um número cada vez maior de clientes. O Clube Náutico, que atendia clientes e visitantes mediante reservas nos finais de semana, continuava esporadicamente servindo o prato (também sob reserva), mas desde o término da gestão de Neréa Sarmento em meados da década de 1970 e do afastamento de dona Ieda, agora concentrada em seu próprio restaurante, a iguaria perdeu destaque e também boa parte dos clientes.

Em 1981, a oferta do Barreado ganhou reforço em Antonina. Nesse ano foi inaugurado o Restaurante Caçarola do Joca, fundado por Joaquim Carlos Alcobas, um paulistano que até então trabalhava no ramo da confecção, chegou a Antonina em 1974 e se iniciou na área da alimentação com o próprio Caçarola, cuja capacidade (quarenta e dois lugares "folgado" e cinquenta lugares "apertado") e localização se mantêm inalteradas desde sua abertura. $\mathrm{O}$ entrevistado comprou o restaurante, que já funcionava havia dois anos, e fez pequenas adaptações antes de reinaugurá-lo. O Barreado faz parte do cardápio desde a reabertura da casa, pois "o Barreado é um dos carros chefes do litoral, você não pode deixar de ter" (ALCOBAS, 2008). Tal popularidade se reflete no fato de que, até hoje, o prato figura entre os mais vendidos da casa, ao lado da casquinha de siri. Verifica-se que, apesar de não ser a intenção inicial, o restaurante de Alcobas também se orientou para o atendimento de visitantes, tendo maior movimento aos sábados, domingos e feriados.

Em 1982, foi a vez de Morretes ganhar um novo estabelecimento voltado para o Barreado. Foi neste ano que o empresário Gilmar Cunha, segundo ele mesmo "morretense teimoso, nascido e criado", e sua esposa Jeanete Cunha, natural de Campo Mourão, abriram o Lubam, cujo cardápio se resumia basicamente à combinação do Barreado com frutos do mar. $\mathrm{O}$ casal iniciou-se na área da alimentação quando arrendou do cunhado o Bar Tropical, que gradativamente foi transformado em restaurante. Diante da ideia de começar a trabalhar com o Barreado congelado e expandir os negócios, o casal comprou o terreno em que se encontra atualmente o restaurante,

6 O Restaurante Danúbio Azul foi fundado em 1954 e adquirido pelo pai do atual proprietário João Carlos Carmezin em 1963. Atualmente o mais antigo restaurante em funcionamento da cidade, o estabelecimento foi reformulado pela família Carmezin, e sempre teve na oferta de frutos do mar sua especialidade. O Barreado foi introduzido no cardápio do restaurante na década de 1980 e permanece até hoje como uma das várias opções da casa. 
realizou as edificações e, em 1982, inaugurou a casa, com a denominação de Lubam, com cento e trinta lugares. O Barreado congelado foi lançado em vários supermercados de Curitiba e do Paraná, e também passou a ser vendido em um quiosque anexo ao restaurante, em funcionamento até os dias de hoje.

O Barreado, que agora podia ser degustado em Antonina no Restaurante da Ieda e na Caçarola do Joca, em Morretes no Hotel Nhundiaquara, no Restaurante Madalozo e no Restaurante Lubam, e em Paranaguá no Restaurante Danúbio Azul, ganhou destaque em Curitiba durante o Festival do Barreado e do Fandango. Realizado entre 29 e 31 de outubro de 1982 nas dependências do SESC-Portão, o Festival foi uma promoção do SESC e da Associação Tradicionalista Gralha Azul. Durante o evento, de divulgação estadual, foi distribuído um encarte que trazia explicações sobre o Barreado, o fandango e ainda algumas receitas com pinhão. A história do Barreado era apresentada e ele era apontado como um prato litorâneo, sem que se especificasse o município de sua origem ou onde poderia ser degustado. Também constava do folheto uma receita do prato, em que se mencionavam algumas peculiaridades de seu preparo - inclusive o modo de fazer o lacre da panela (SESC, 1982).

Em 1982, com a morte de seu primeiro marido, o Barão André, dona Ieda passou o restaurante para sua residência, ao lado do Clube Náutico, o que ampliou em muito a capacidade do estabelecimento. No mesmo ano, a empresária levou o Barreado para São Paulo, para ser servido na Primeira Feira de Artesanato e Comidas Típicas do Brasil, como convidada da Paranatur (então Empresa Paranaense de Turismo), na qualidade de representante do Paraná, juntamente com outro restaurante, o Restaurante Veneza, que servia comida italiana. Ela conseguiu recursos para participar do evento fazendo um empréstimo no Banco, e foi recompensada: foram vendidos os quinhentos quilos de Barreado preparados para a ocasião. A Prefeitura de Antonina, segundo a entrevistada, não lhe prestou nenhum apoio e nem agradeceu sua iniciativa de divulgar a cidade junto com o prato.

Em novembro do mesmo ano a oferta do Barreado em Antonina foi fortalecida. Leônidas Gaspar de Abreu, nascido em Curitiba em 1953, inaugurou o Restaurante Panorâmico Albatroz. O empresário, que até então trabalhava como auxiliar de fiscal aduaneiro na Receita Federal, retornou a Antonina por motivo de doença da mãe e resolveu estabelecer-se na cidade, 
onde tinha passado sua infância e adolescência. Ele abriu um bar chamado Fim de Noite em 1985, que funcionava às sextas e sábados. Como acreditava no potencial da área de alimentação, no mesmo ano transformou o bar em um restaurante: "na época tinha muita fila, fazia uma fila enorme. Pô, tinha fila até cinco, seis horas da tarde pro almoço! Foi quando eu resolvi abrir um restaurante também" (ABREU, 2008). O Restaurante Panorâmico Albatroz foi inaugurado com capacidade para cento e quarenta pessoas (que se mantém até hoje), atendendo principalmente turistas e visitantes, característica que ainda prevalece.

Sobre o cardápio, Leônidas enfatiza que o Barreado sempre esteve presente, desde o primeiro dia. Explicando o porquê da inclusão do prato, o empresário defende de maneira até inflamada a ligação de Antonina com a iguaria: "Resolvi incluir exatamente pelo fato do Barreado ser um carro-chefe de Antonina e não do litoral [...] Eu falo isso para quem quiser ouvir que o Barreado é de Antonina. Então não tinha como não incluir no cardápio!" (ABREU, 2008).

Ainda em 1986, outro restaurante que destacava (e ainda o faz) o Barreado em seu cardápio foi inaugurado em Antonina. O Restaurante Buganvil's foi fundado por Hendrika Snoeyer, ou Anny, como prefere ser chamada, uma holandesa que chegou com a família no Brasil em 1948 e, no Paraná, em 1961. Conheceu o litoral paranaense por intermédio de seu ex-marido, um belga apaixonado por barcos e se encantou pela cidade. Anny mudou-se definitivamente para Antonina em 1986 e adaptou a propriedade que usava no período de veraneio para abrigar o restaurante. A empresária salienta que sempre incluiu o Barreado no cardápio "porque tem muita gente que vem só pelo Barreado, não tem como não ter" (SNOEYER, 2008). Mas faz questão de manter "um toque holandês" em peixes, grelhados, camarões e legumes.

Antonina, então, passava a contar com o Restaurante Caçarola do Joca, o Restaurante Panorâmico Albatroz e o Restaurante Buganvil's divulgando e oferecendo o Barreado na cidade, além do Restaurante da Ieda, o mais famoso e disputado. O Cacoan recebia excursões de ônibus, atendia grupos que chegavam pelo trem e ainda estabeleceu importantes parcerias com a Vasp e a Varig.

Em 4 de agosto de 1989, o jornal O Estado do Paraná publicou uma reportagem intitulada "Barreado, um pouco de nossa história". A reportagem apresentava o Barreado como "prato típico do Paraná, que 
nasceu do litoral do estado", indicando os restaurantes em Curitiba e no litoral nos quais se podia, na oportunidade, degustá-lo. A reportagem, com caráter informativo e turístico evidente, identificava tais estabelecimentos, inclusive informando endereço e telefone.

O ano de 1989 ficou marcado pelo início da gestão de Sebastião Cavagnolli na Prefeitura Municipal de Morretes e pelo fechamento do Restaurante da Ieda, em Antonina, por razões pessoais da proprietária. O prefeito Sebastião Cavagnolli, já falecido, é apontado, por morretianos, capelistas e parnanguaras, como o grande responsável pelo desenvolvimento do turismo em Morretes e sua associação ao prato. Contudo, ao se falar desta gestão é impossível não comentar a atuação de Orley Antunes de Oliveira Junior, responsável pela área de turismo durante o governo daquele prefeito (Gestão 1989-1992).

A primeira ação de impacto da Gestão Cavagnolli procurou unir uma atividade de lazer do morretiano e a divulgação do município com a amenização dos problemas causados pela enchente: a descida do rio de boia (câmaras de pneus), ali no distrito de Porto de Cima. A ideia deste boia-cross não era premiar quem chegasse primeiro, mas sim quem recolhesse maior quantidade de lixo em sua boia. $\mathrm{O}$ evento foi divulgado pela televisão, inclusive em programas nacionais da Rede Globo e também pela mídia impressa. A primeira edição do boia-cross ecológico aconteceu em fevereiro e recolheu do rio aproximadamente cinco toneladas de lixo. Para Oliveira Junior (2008), contudo, o grande resultado positivo do evento foi a confiança adquirida: "de tanta gente que veio, mostrou para as pessoas que Morretes tinha muito carisma. Mostrou para o próprio prefeito e para a própria cidade, deu aquele sentimento de "nós podemos! Nós podemos mudar a cidade!"

A partir do sucesso do primeiro evento, as atenções se voltaram para o Barreado. Divulgar a iguaria amplamente, no Brasil e no exterior, foi a meta perseguida nos anos seguintes, em vários eventos no Brasil e no exterior. Com o slogan "Morretes, Terra do Barreado", Cavagnolli começou a divulgar maciçamente o prato associado à cidade. Um dos materiais promocionais distribuídos nesses eventos era um folheto no formato A4 intitulado "Barreado: prato típico de Morretes", estampando uma panela de barro contendo a iguaria ao lado de uma farinheira. O texto tem apelo turístico claro: "aqueles que pela primeira vez visitam o Paraná, mais precisamente o litoral paranaense, ficam conhecendo um prato muito gostoso 
que lhes é completamente novo: o Barreado" (PREFEITURA MUNICIPAL DE MORRETES, 1989).

De acordo com Orley, algumas pessoas de Antonina não gostaram da repercussão alcançada na vinculação do Barreado a Morretes. Segundo o entrevistado, "Antonina se incomodou, falando que a gente dizia que o Barreado era só nosso. A gente não fez nada disso. A gente divulgava Morretes, Terra do Barreado, nem questionávamos Antonina. Nosso negócio era Morretes" (OLIVEIRA JUNIOR, 2008). Contudo, o entrevistado fez questão de comentar um antigo boato sobre as razões que fizeram a oferta comercial do Barreado crescer tanto em Morretes: "Essa coisa que em Morretes teve subsídio da Prefeitura pra abrir restaurante, isso nunca aconteceu. A gente divulgava a cidade e o prato, e o resto ficava por conta deles [dos empresários]. Não teve isenção de imposto, nada disso" (OLIVEIRA JUNIOR, 2008).

Deve-se observar, porém, que, como o próprio entrevistado admite, Orley é uma figura bastante polêmica. Para Joaquim Alcobas, ele realmente conseguiu associar Morretes ao Barreado, mas o fez em detrimento da divulgação de Antonina. Ana Eliza Correia de Souza, de Antonina, tem uma opinião semelhante. Segundo ela, Morretes soube aproveitar melhor as oportunidades, inclusive participando de eventos na área de turismo, como os promovidos pela ABAV (Associação Brasileira de Agências de Viagens).

É fato que, com o fechamento do principal restaurante e a mudança de dona Ieda da cidade, Antonina perdeu também a principal personagem da história do Barreado litorâneo. Por outro lado, a política de divulgação intensiva promovida por Morretes fez com que na próxima década o prato estivesse muito mais vinculado a Morretes do que a Antonina, revertendo o quadro que se apresentava na década de 1970. Paranaguá, por sua vez, mantinha uma oferta comercial inexpressiva, mantendo o Barreado nas residências e, apenas em meados de 1990, teria uma divulgação mais evidente, sempre associado ao Fandango.

\subsection{A CONSOLIDAÇÃO DO BARREADO}

Em 1991, em Morretes, foi inaugurado o Restaurante Panorâmico Ponte Velha, o segundo maior restaurante da cidade. Seu proprietário, Joaquim de Souza Júnior, parnanguara, descendente de mãe polonesa e pai por- 
tuguês, nascido em 1939, mudou-se para Morretes em 1945. O empresário posteriormente morou vinte e dois anos em Curitiba, aposentou-se como contador e retornou a Morretes com a esposa, acreditando no potencial turístico, inclusive pela proximidade com Curitiba.

O futuro empresário realizou pesquisas de demanda e pensava, inicialmente, em abrir um espaço para eventos. O restaurante foi inaugurado com cento e cinquenta lugares, na localização em que está até hoje, na frente do Restaurante Madalozo, o mais tradicional da cidade. Segundo o entrevistado, a demanda crescente que se avolumava às portas do Madalozo foi determinante para a decisão de abrir seu restaurante.

Não apenas pela localização, mas também pela capacidade de seu salão, o Restaurante Ponte Velha tornou-se de imediato o principal concorrente do Restaurante Madalozo. Como estratégia de lançamento do estabelecimento, Joaquim adotou uma política de preços agressiva em relação ao seu principal concorrente, acirrando ainda mais os ânimos: "nós tivemos a ideia de abrir um prato que vem a ser o prato completo, o Prato Ponte Velha. Porque todos vêm à procura do Barreado e mais um complemento, então os frutos do mar, à época só um real a mais no valor prato principal" (SOUZA JUNIOR, 2008). O tino empresarial de Joaquim não se limitou ao registro do nome do restaurante como propriedade industrial; ele registrou também o prato que ele chama de Ponte Velha, ou ainda PV (Barreado, frutos do mar e complementos).

Deve-se observar que o Ponte Velha foi concebido para atender a uma demanda gerada pelo próprio Barreado, ao contrário de alguns restaurantes que já existiam na região e que incorporaram posteriormente o prato aos seus cardápios. Isso se deu porque, graças à clientela conquistada pelos outros restaurantes e à fama adquirida com a divulgação promovida pela Gestão Cavagnolli, a imagem de Morretes já estava associada e consolidada com o Barreado. Mesmo servindo outros pratos, inclusive a caldeirada, exclusividade de seu estabelecimento, o empresário conta: "sempre servimos o Barreado e não dá para tirar, muito pelo contrário! A razão da existência desse movimento é o Barreado. Eu perguntaria: 'quem desceria a serra pra comer frango, polenta, radiche e outras comidas italianas?' [...] Então Morretes tem que manter essa tradição!” (SOUZA JUNIOR, 2008).

Em agosto de 1992, foi aberto o Restaurante Casarão, por Maurício Scucazo dos Santos, engenheiro químico, administrador de empresas e eco- 
nomista, nascido em Morretes em 1965. O empresário assumiu junto com a futura esposa um imóvel que havia sido passado para o sogro, o reformou e abriu ali o Casarão. A casa, aberta com duzentos lugares, sempre teve o Barreado como carro-chefe: "as pessoas vêm para comer o Barreado. Até pra fazer um comparativo, o pessoal vai para Santa Felicidade para comer frango com polenta e aqui ele vem para comer Barreado. Tudo acompanha o Barreado" (SANTOS, 2008).

Em 1992, a gestão Cavagnolli em Morretes chegou ao fim. Fazendo uma análise do período, Orley comenta que muitos empresários, como os proprietários do Casarão e do Ponte Velha, retornaram a Morretes porque viram uma possibilidade: a cidade crescia por conta do Barreado. E muitas chácaras destinadas para divertimento familiar também começaram a ser adaptadas como pousadas.

Em 1993, foi a vez de Paranaguá ter sua gestão do turismo dinamizada. No início do ano, assumiu o novo prefeito, Carlos Tortato, que renovou o quadro administrativo municipal, chamando Sandra Leal para presidir a FUMCULTUR - Fundação de Cultura e Turismo - e Dirce Felisbino da Silva para integrar o corpo técnico da Diretoria de Turismo. Ao ingressar na FUMCULTUR, onde permaneceu até 2003, Dirce deparou-se com um Departamento de Turismo cujo histórico se resumia aos aspectos operacionais da organização de eventos como o aniversário da cidade ou a Festa da Padroeira. A questão da cidadania e do resgate da autoestima do parnanguara foram então colocadas como prioridade e esforços foram orientados para a valorização do fandango, uma das principais manifestações populares da localidade.

A Fundação fez então um trabalho cuidadoso, envolvendo fandangueiros e realizando seminários sobre folclore, tentando envolver os moradores mais jovens. Na época, segundo Dirce, ainda não se trabalhava de forma específica com o Barreado, mas na medida em que o trabalho com o Fandango ganhava fôlego, "uma coisa foi puxando a outra: já que a gente estava falando de folclore, falando de fandango e sabia que o Barreado era associado a ele, então começamos a trabalhar ele também" (SILVA, 2008).

Em 1993, a oferta do Barreado em Morretes foi fortalecida, com a inauguração do Restaurante Armazém Romanus. Seu proprietário, Luis Antonio Romanus, abriu o restaurante com capacidade para cinquenta pessoas, no endereço em que permanece até hoje. O público-alvo, desde a 
abertura do estabelecimento, é composto por "pessoas que gostam de uma comida elaborada, gourmet, feita na hora. Com exceção do Barreado que é um prato que se leva dois dias para preparar, os outros pratos são feitos na hora" (ROMANUS, 2008). Com um cardápio extenso, composto por mais de oitenta itens, dentre eles pratos internacionais, o chef e empresário observa que sempre teve no Barreado o seu prato principal, velho conhecido de sua família por conta da esposa, natural de Morretes. A receita de seu restaurante inclusive é de família, tem mais de cem anos e é a mesma receita que a bisavó de sua esposa preparava.

No ano seguinte, Morretes ganhou mais um restaurante dedicado ao Barreado: o Restaurante My House, de propriedade de Gilberto Malucelli, filho de uma tradicional família morretiana. O empresário diz que tinha uma casa muito bem situada (nas margens do Rio Nhundiaquara, ao lado do Hotel e Restaurante Nhundiaquara), e a partir dela viu uma oportunidade de negócio. Quando se aposentou, ponderou sobre o diferencial que seu imóvel, inicialmente residencial, oferecia. O Barreado sempre foi o principal prato da casa, servindo inclusive para algumas inovações. O restaurante, que também funciona como pizzaria à noite, tinha a intenção de lançar a pizza de Barreado no cardápio de 2008.

Em Paranaguá, no mesmo ano, o Barreado recebeu destaque a partir de sua associação com o fandango. Segundo Dirce da Silva, em 1994 foi realizado o Festival Internacional de Folclore em Paranaguá, cujo público chegou a doze mil pessoas. O Barreado foi preparado com o patrocínio da Associação Comercial e servido a todos os participantes. A ex-diretora de Turismo de Paranaguá relembra que foi a partir do sucesso deste evento que conseguiram despertar o interesse dos jovens para o fandango: a repercussão foi tanta que mais de oitenta jovens se inscreveram para as doze vagas oferecidas no Grupo Folclórico Mestre Romão, que objetivava resgatar e divulgar o folguedo. A divulgação do Barreado, por sua vez, sempre acontecia conjugada com o fandango. Segundo a entrevistada, em todo evento em que era levado o Fandango era levado também o Barreado.

Contudo, revela Dirce, a boa repercussão da divulgação do Barreado em outros lugares não encontrava sustentação dentro do próprio município: "a gente tinha um problema muito sério: a gente divulgava o Barreado lá fora, mas as pessoas diziam 'Tem Barreado em Paranaguá?' 'Mas onde, se eu vou lá e não encontro Barreado?' 'Em que restaurante?'” 
(SILVA, 2008). Para ela, o fato de as pessoas prepararem o Barreado em casa no Carnaval e também fora dele fazia com que os restaurantes não explorassem comercialmente sua oferta.

O comentário de Dirce reflete a escassez de material promocional relacionando Paranaguá ao Barreado até a década de 1990. O esforço do poder público dirigido ao resgate da manifestação alcançou boa repercussão, mas foi prejudicado pela ausência da oferta comercial da iguaria. $\mathrm{O}$ Restaurante Danúbio Azul, o mais antigo e prestigiado da cidade, servia o Barreado, mas tinha como especialidade os pescados e frutos do mar, relegando o tradicional prato a uma posição de pouco destaque.

Este panorama foi alterado em 1996, quando Norma Santos de Freitas abriu a Casa do Barreado, um restaurante com a proposta de recuperar e divulgar o tradicional Barreado e que nasceu com capacidade para atender quarenta pessoas, servindo também frutos do mar. $\mathrm{O}$ restaurante teve desde o início um público formado por turistas e visitantes, o que estimulou a proprietária a se aproximar ainda mais da área, inclusive por meio de participação nas oficinas do $\mathrm{PNMT}^{7}$. O esmero em preparar uma receita artesanal na tradicional panela de barro logo diferenciou o restaurante dos demais da cidade, que muitas vezes oferecem o prato apenas como opção do buffet. Este cuidado chamou a atenção da Paraná Turismo, que passou a convidar a cozinheira e empresária para servir o prato em vários eventos de divulgação do Estado no Brasil e no exterior.

Em Antonina, no ano 2000, foi inaugurado o restaurante Le Bistrot, que anteriormente funcionava como lanchonete e pizzaria. Os proprietários que assumiram o estabelecimento na oportunidade, Ana Eliza Correia de Souza e seu esposo Telmo de Souza, ambos capelistas, introduziram o "rodízio de frutos do mar, um prato para ser servido por pessoa e à vontade. Então o objetivo de abrir a casa foi trabalhar com frutos do mar e Barreado, a comida típica da nossa região mesmo" (CORREIA DE SOUZA, 2008). Inaugurado com capacidade para cem lugares, a casa abriu oferecendo Barreado e frutos do mar no sistema rodízio e outros pratos no sistema à la carte, incluindo algumas opções de carne.

7 Programa Nacional de Municipalização do Turismo, foi implantado no período de 1994 a 2007 e tinha como característica uma abordagem comunitária participativa que buscava sensibilizar, conscientizar e capacitar representantes dos municípios para o turismo. 
Em Morretes, também no ano 2000, Nelson Nei de Souza da Silva e sua esposa, Márcia da Costa Silva, inauguraram o restaurante Serra e Mar, localizado na região central da cidade, mas longe das margens do Nhundiaquara. $\mathrm{O}$ empresário também começou com uma lanchonete e apenas posteriormente transformou o negócio em um restaurante. Quando foi feita esta transição, o Barreado não fazia parte do cardápio, porque a clientela era formada pelos próprios moradores. Ele foi incluído quando o Serra e Mar foi instalado no atual endereço e o estabelecimento também voltou-se para os turistas. "E para o turismo tem que ter o Barreado!" (SILVA, 2008).

No mesmo ano, Morretes ganhou mais um reforço na oferta do Barreado: foi inaugurado o restaurante Terra Nossa. A proprietária, Maria Júlia Stopinski, abriu o restaurante com o marido, um ex-bancário. A proposta inicial era voltada aos moradores da cidade, mas logo os turistas se tornaram $\mathrm{o}$ foco. A princípio a casa só abriria à noite, mas passou a funcionar também no almoço. E o Barreado passou a integrar o cardápio da casa, inicialmente concebida para ser exclusivamente uma pizzaria. "As pessoas chegavam, perguntavam se tinha Barreado e muitas vezes iam embora, porque não tinha" (STOPINSKI, 2008).

Em 2002, em Antonina, Joaquim Ferreira dos Santos Filho, nascido em 1961, em São Paulo, inaugurou o restaurante Cantinho de Antonina. O empresário tinha um botequim e, incentivado por um grupo de clientes, mudou-se para Curitiba em 1991, onde abriu o restaurante Cantinho de Antonina, que funcionou na capital por 15 anos. O Barreado sempre fez parte do cardápio, juntamente com frutos do mar e a casquinha de siri. Transparecendo um entusiasmo incomum aos demais empresários da cidade, ele conta que retornou em 2002 e logo na sequência inaugurou seu novo estabelecimento, com o mesmo nome que o anterior: "Foi uma das melhores coisas que eu fiz nesses últimos anos, porque cheguei numa hora boa em Antonina. Essa área aqui é muito visitada por turistas, então acabei me dando bem de novo com o meu restaurante" (SANTOS FILHO, 2008). O restaurante, com serviço à la carte e capacidade para sessenta pessoas, foi inaugurado na Ponta da Pita, localidade bastante popular nas décadas de 1970 e 1980. Com o próprio Joaquim encarregado da cozinha, a casa abriu com apenas três funcionários e estava em mudança de localização quando a entrevista foi realizada.

No que tange à oferta do Barreado no litoral, em 2003 a Prefeitura Municipal de Paranaguá distribuiu um folheto intitulado Barreado: prato 
típico do Litoral do Paraná, apresentando um pequeno histórico do prato, sua receita para dez pessoas e listando quais restaurantes serviam o Barreado na cidade: Casa do Barreado (almoço aos sábados, domingos e feriados), Mercado Municipal do Café - Box Santo Antonio (almoço à la carte todos os dias), Restaurante a Bonbonnee (Buffet no almoço aos domingos e à $l a$ carte todos os dias), Restaurante a Bombordo (somente por encomenda) e Restaurante Camboa do Camboa Hotel (almoço aos sábados) e Restaurante Danúbio Azul (buffet no almoço e à la carte no jantar, todos os dias). $\mathrm{O}$ folder, que tinha como objetivo tornar mais concreta a oferta do prato aos olhos dos turistas e visitantes, foi assinado pela Prefeitura de Paranaguá, FUMTUR/COMTUR e Barreado Paranaguá.

Ainda em 2004, o Restaurante Madalozo realizou mais uma de suas ampliações. A casa, que começou com 250 lugares na sede às margens do Rio Nhundiaquara, foi ampliada pela primeira vez em 1988, com a abertura de um novo salão com sacadas que somavam mais 200 lugares. Em 1992, foi construída uma sacada para a ligação entre os dois salões, acrescentando 40 lugares. Em 2000, foi construído o terceiro salão, somando mais 200 lugares à estrutura já existente. Na última ampliação, ocorrida em 2004, foi inaugurado um quarto salão, com capacidade para 120 lugares, que é usado habitualmente como sala de espera.

Em 2005, Morretes ganhou mais um restaurante, o Estação Graciosa, por iniciativa de Simone Aparecida Casilha e de seu irmão. A casa, com capacidade para oitenta pessoas, foi aberta com oito funcionários, além de contar com os irmãos no gerenciamento e também na operacionalização. Direcionada para turistas e concebida inicialmente para trabalhar com carnes nobres (diante da ausência de churrascarias na cidade), principalmente na brasa, o Barreado só foi incorporado mais tarde. A ideia inicial era criar um diferencial, "mas o público exigiu o Barreado. [...] A gente tentou uns seis meses sem o Barreado, mas daí não teve jeito. Todo mundo entrava e dizia: 'O quê? Não tem Barreado? Eu vim para Morretes para comer Barreado!'” (CASILHA, 2008).

Em 2005, em Morretes, foi fundada a ARSIM - Associação dos Restaurantes e Similares de Morretes, por um grupo de empresários do setor de alimentação daquela cidade. Falando sobre a criação da Associação, Mauricio Leite Laffitte, atual presidente, afirma que há aproximadamente doze anos a Associação Comercial de Morretes (criada no início da década 
de 1990) possuía uma câmara setorial que discutia questões específicas dos restaurantes. Este grupo foi se fortalecendo até que surgiu a ideia de fundar uma associação dos restaurantes, cujo primeiro presidente foi Gilberto Malucelli, do Restaurante My House. AAssociação trabalha principalmente com a divulgação da cidade, informação e qualificação de técnicas e serviços de restauração, além de discutir questões de caráter administrativo, como os preços praticados pelos fornecedores de insumos em geral.

Em Antonina, em 2006, o Restaurante Buganvil's se mudou para a região central da cidade, próxima à Igreja Matriz, procurando, com a nova localização, maior visibilidade e a ampliação da clientela. No mesmo ano, em dezembro, foi aberto em Morretes o Restaurante Villa Morretes por Maurício Scucazo dos Santos, já proprietário do Restaurante Casarão. Segundo o empresário, a motivação para a abertura do restaurante se deu por conta da demanda dos próprios clientes, que pediam ingredientes mais sofisticados, um atendimento diferenciado e uma área de circulação maior. O estabelecimento foi inaugurado com oitenta lugares no salão e quarenta lugares no bosque, que é o grande diferencial da casa. Dentro da proposta de apresentar outro padrão de atendimento, o Villa oferece o Barreado em um buffet em fogão a lenha e conta com um funcionário para servir os clientes e, caso eles desejem, preparar o famoso pirão escaldado.

Em 21 de abril de 2007, foi inaugurado o Restaurante Olimpo, de Moisés Batista dos Santos, parnanguara que reside em Morretes há aproximadamente vinte anos. Chegou à cidade para trabalhar na Caixa Econômica, onde permaneceu até dezembro de 2007, quando decidiu abandonar a carreira de bancário para tornar-se exclusivamente empresário. Quando optou por abrir o restaurante, Moisés era proprietário de três lojas na cidade, o Carmem Maria Artesanato, o Carmem Maria Decoração e Presentes e o Armazém do Artesanato, todas em sociedade com a esposa. $\mathrm{O}$ entrevistado começou a construção do restaurante (no primeiro piso possui uma de suas lojas de decoração) e pretendia arrendar o estabelecimento, mas resolveu tocar o restaurante: "A gente observava já que as pessoas estavam procurando mais Morretes e que fazia muita fila nos restaurantes. Então eu vi uma possibilidade para explorar" (SANTOS, 2008). O Restaurante Monte Olimpo, desde sua abertura, possui o Barreado no cardápio. Sobre a inclusão do prato, o empresário comenta a expectativa das pessoas que se deslocam até Morretes para degustar o prato: não oferecê-lo é perder 
clientes. Outro aspecto comentado é a ideia de fartura que foi associada a Morretes: o sistema de rodízio se tornou tão popular que, mesmo que haja desperdício, é solicitado pela clientela.

No ano seguinte, a oferta do Barreado em Morretes ganhou mais um reforço. Foi inaugurado o Restaurante Empório do Largo. O proprietário, um jovem engenheiro civil chamado Luis Guilherme Camargo Peralta, decidiu investir na cidade, mesmo residindo em Curitiba. O empresário decidiu abrir um restaurante no centro histórico de Morretes, aproveitando uma antiga propriedade da família que já havia sido usada no ramo da alimentação.

Ao final de 2008, em Antonina nove restaurantes dedicavam-se ao Barreado, tendo-o como prato principal ou complementar. Em Paranaguá, este número era de sete estabelecimentos. A oferta do Barreado em Morretes, no entanto, constatou-se ainda mais fortalecida, contando com dezoito estabelecimentos dedicados ao Barreado, tendo na iguaria seu atrativo principal ou complementar. Anos mais tarde, verifica-se que as iniciativas do senhor Antonio Alpendre, do senhor Honílson Madalozo e de dona Ieda Siedschlag terminaram não apenas por dar nova amplitude ao preparo e consumo do prato, mas também constituíram uma importante fonte de geração de empregos e desenvolvimento para Antonina, Morretes e Paranaguá.

\section{Considerações finais}

O Barreado, um inusitado prato litorâneo à base de carne, destaca-se no contexto paranaense pela longevidade de sua degustação e pelos laços que estabelece com outras práticas culturais, como o fandango e o Carnaval. Acredita-se, inclusive, que a íntima relação com outras manifestações litorâneas, somada ao fato de o prato ter como elemento principal um ingrediente que durante muitos anos foi considerado "especial" (por conta de seu preço, a carne era reservada a ocasiões especiais), além de seu sabor forte e característico (produto principalmente da ação do cominho), favoreceu a popularidade do prato e facilitou seu destaque dentre os demais da cozinha do litoral.

Evidencia-se também como um prato de notoriedade nacional alcançada por meio da articulação e desenvolvimento da atividade turística 
na região, sendo capaz de despertar o interesse para visitação e movimentar economicamente as cidades associadas ao seu consumo, especialmente Morretes. Neste sentido, o prato emerge como tradição, mas também como um legado que é operacionalizado e ofertado em caráter comercial, sendo divulgado e disponibilizado a um público ainda maior, mas também exposto com maior intensidade aos perigos da descaracterização.

A partir da pesquisa realizada ficou evidente que o saber-fazer do Barreado conjuga tradições e inovações tanto no domínio do privado, do familiar, quanto no domínio do público, dos restaurantes. Mesmo aqueles que afirmam fazer o "Barreado tradicional" acabam não escapando de pelo menos alguma forma de modernização, ou até mesmo atualizações da tecnologia, como é o caso do uso do fogão a lenha. Dentre as alterações, a mais polêmica - mas talvez a mais difundida - seja a substituição da panela de barro pela panela de alumínio no preparo da iguaria. A obrigatoriedade de atender à longa lista de exigências da ANVISA, a preocupação com a segurança dos funcionários (de acordo com as panelas que trincaram ou quebraram no fogo) e até mesmo a necessidade de preparar grandes quantidades são os argumentos em favor desta mudança, detectada tanto nas casas quanto nos estabelecimentos.

Deve-se enfatizar a importância da gestão de Cavagnolli, durante a qual o Barreado assumiu sua vocação turística em Morretes e houve um trabalho para ampliar e intensificar os fluxos de comensais que até então aconteciam quase que naturalmente, baseando-se na boa aceitação dos restaurantes e na propaganda boca-ouvido diante da inexistência de ações administrativas promocionais dirigidas. A partir de 1989 foram abertos quinze dos dezoito estabelecimentos dedicados ao Barreado em funcionamento na cidade e tal demanda é tamanha que alguns estabelecimentos que originalmente não previam o Barreado em seus cardápios terminaram por adotá-lo diante da exigência de seus clientes.

Nesse período, Morretes consagrou-se como "Terra do Barreado", perspectiva que se mantém até hoje, dada a íntima relação que se estabelece entre o município e a iguaria. A partir da popularidade do prato, cresceu não apenas o número de restaurantes, mas também um ramo de hospedagem, bem como verificou-se o crescimento das lojas de artesanato e o fortalecimento do comércio em geral. Em síntese, em torno do Barreado se criou um intenso e dinâmico quadro articulando comida, turismo e desenvolvimento. 
Antonina, que já havia sido o principal local de degustação da iguaria, principalmente por conta da popularidade de dona Ieda, começou a perder terreno, tendo em vista a falta de reação diante da campanha maciça empregada por Morretes na gestão Cavagnoli, a ausência de investimento no turismo e ainda o fechamento de seu principal restaurante (o Restaurante Cacoan, ou, como era chamado, da Ieda). A oferta do Barreado permanece no município, ganhando destaque na maioria dos restaurantes, mas se mantém à margem de Morretes inclusive por conta da pequena opção de lazer que a cidade oferece.

Em Paranaguá, o Barreado ganhou evidência quando o fandango começou a ser recuperado pela FUMCULTUR, visando ao resgate da autoestima e cidadania de seus habitantes, além da complementação de sua oferta turística. Entretanto, mesmo sendo preparado nas residências, a ausência de restaurantes especializados na iguaria terminou por prejudicar as estratégias adotadas pelo poder público de divulgar intensamente o prato. Outro aspecto que parece não ter favorecido o fortalecimento da associação Barreado-Paranaguá é o fato de que, tradicionalmente, os restaurantes locais possuem como carro-chefe os frutos do mar e são conhecidos a partir de tal especialidade.

Analisando o quadro geral, observa-se a oferta comercial do Barreado nasceu voltada naturalmente para os visitantes, sem que houvesse um planejamento orientando o processo. Da mesma forma, pode-se constatar que o Barreado realmente se constituiu como um elemento estratégico para o desenvolvimento de Antonina, mas principalmente de Morretes. Os restaurantes de Paranaguá, como mencionado, terminaram se dedicando aos frutos do mar ou ao atendimento dos fluxos gerados pelo próprio porto, oferecendo uma comida mais convencional, enquanto a iguaria Barreado era projetada do ponto de vista da gestão pública sempre associada ao fandango.

Pode-se afirmar, portanto, que a oferta comercial do Barreado não apenas se estabelece graças à boa aceitação dos visitantes, mas é sob a ótica da atração de visitantes (e, portanto, sob a ótica turística) que se expande, contribuindo para a ampliação da divulgação da iguaria de uma forma que seria impensável caso a mesma se mantivesse circunscrita às residências e festas populares. Neste sentido, se por um lado a oferta comercial do Barreado termina por expor a iguaria a uma série de possibilidades de alteração, por outro lado é justamente esta ampliação da oferta que divulga e fortalece 
a tradição do Barreado, inclusive incutindo nos moradores das localidades estudadas o desejo de defender "o verdadeiro Barreado", que geralmente consideram como aquele preparado em seu município. O Barreado, nesse sentido, constrói identidades, agregando significados e se caracterizando como um elemento identitário representativo, reivindicado como símbolo de um passado que se deseja valorizar.

\section{Fontes orais (apenas as citadas neste artigo)}

ABREU, L. G. (Tata). Entrevista. Antonina, 26 de março de 2008. MP3, 1h20min. ALCOBAS, J. C. Entrevista. Antonina, 11 de março de 2008. MP3, 0h36min.

CASILHA, S. A. Entrevista. Morretes, 08 de maio de 2008. MP3, 0h29min. CUNHA, G. Entrevista. Morretes, 08 de maio de 2008. MP3, 0h30min.

FREITAS, N. Entrevista. Paranaguá, 09 de julho de 2008. MP3, 0h56min. LAFFITTE, T. B. M. Entrevista. Morretes, 13 de maio de 2008. MP3, 0h59min. MADALOZO, I. I. B. Entrevista. Morretes, 13 de maio de 2008. MP3, 0h49min. MALUCELLI, G. R. Entrevista. Morretes, 09 de maio de 2008. MP3, 0h51min. OLIVEIRA JÚNIOR, O. A. Entrevista. Morretes, 02 de setembro de 2008. MP3, 0h59min.

ROMANUS, L. A. Entrevista. Morretes, 14 de maio de 2008. MP3, 0h34min. SANTOS, M. S. Entrevista. Morretes, 09 de maio de 2008. MP3, 0h24min. SANTOS FILHO, J. F. Entrevista. Antonina, 13 de abril de 2008. MP3, 1h03min. SIEDSCHLAG, I. Entrevista. Matinhos, 04 de setembro de 2008. MP3, 1h42min. SILVA, D. F. Entrevista. Paranaguá, 03 de setembro de 2008. MP3, 0h57min. SOUZA, A. E. C. Entrevista. Antonina, 13 de março de 2008. MP3, 0h32min. SILVEIRA, M. G. A. Entrevista. Morretes, 08 de maio de 2008. MP3, 0h54min. SNOEYER, H. W. (Anny). Entrevista. Antonina, 05 de março de 2008. MP3, 0h40min.

SOUZA JUNIOR, J. Entrevista. Morretes, 27 de maio de 2008. MP3, 1h32min. STOPINSKI, M. Entrevista. Morretes, 07 de maio de 2008. MP3, 0h42min. 


\section{Referências}

BALHANA, A. P.; MACHADO, B. P.; WESTPHALEN, C. M. História do Paraná. Curitiba: Grafipar, 1969, v. 1.

BARREADO, um pouco da nossa História. O Estado do Paraná, Curitiba, 04 ago. 1989.

BARREADO, único prato típico do Paraná. Panorama, Curitiba, n. 136, p. 31, set. 1963.

BOURDIEU, P. Gostos de classe e estilos de vida. In: ORTIZ, R. Sociologia. São Paulo: Ática, 1983.

CAMARGO FILHO, W. P. et al. Evolução da produção do tomate no Brasil. Agricultura em São Paulo, São Paulo, n. 41, v. 1, p. 41-69, 1994.

CARNEIRO, H. Comida e sociedade: significados sociais na História da Alimentação. História: questões e debates, Curitiba: Editora UFPR, n. 42, p. 71-80, 2005.

CASCUDO, L. C. História da alimentação no Brasil. 3. ed. São Paulo: Global, 2004. GIMENES, M. H. S. G. Cozinhando a tradição: festa, cultura e história no litoral paranaense. Tese (Doutorado em História) - Setor de Ciências Humanas, Letras e Artes, Universidade Federal do Paraná, Curitiba, 2008.

GRAMANI, D.; CORREA, J. Naquele tempo, no tempo de hoje: um panorama do Fandango do litoral norte do Paraná e sul de São Paulo. In: PIMENTEL, A.; GRAMANI, D.; CORREA, J. (Org.). Museu vivo do Fandango. Rio de Janeiro: Associação Cultural Caburé, 2006. p. 21-37.

LITORAL e Barreado. Gazeta do Povo, Curitiba, 14 ago.1977.

LOZANO, J. E. A. Práticas e estilos de pesquisa na História Oral contemporânea. In: FERREIRA, M. M.; AMADO, J. (Org.). Usos e abusos da História Oral. 5. ed. São Paulo: Fundação Getúlio Vargas, 2002.

MACIEL, M. E. Uma cozinha à brasileira. Estudos Históricos. Rio de Janeiro, n. 33, p. 25-39, jan.-jun. 2004.

MORAES FILHO, M. Festas e tradições populares no Brasil. São Paulo: Itatiaia, 1979.

NEPOMUCENO, R. Viagem ao maravilhoso mundo das especiarias. Rio de Janeiro: José Olympio, 2003.

PARANÁ TURISMO. Morretes, terra do Barreado. Curitiba: Prefeitura Municipal de Morretes/Governo do Paraná/Paraná Turismo, abr. 2002. 1 folder. 
PREFEITURA MUNICIPAL DE PARANAGUÁ. Barreado: prato típico do Paraná. Paranaguá, 2003. 1 folder.

RANDO, J. A. G. Fandango: contextualização histórica. In: BRITO, M. L. S. (Org.). Fandango de mutirão. Curitiba: Miliart, 2003, p.11-33.

RODERJAN, R. Folclore brasileiro: Paraná. Rio de Janeiro: MEC/SEC/FUNARTE/ Inst. Nacional do Folclore, 1981.

SANTOS, C. R. A. dos. Por uma História da Alimentação. História: questões e debates, Curitiba, v. 14, n. 26/27, p. 154-171, jan./dez. 1997.

. A alimentação e seu lugar na História: os tempos da memória gustativa. Campinas: ANPUH Nacional, 2004.

SESC. Festival do Barreado e do Fandango. Curitiba: SESC Portão Curitiba e Associação Tradicionalista Gralha Azul, 1982. 1 folder.

VIANA, M. Paranaguá na história e na tradição. Paranaguá: Gráfica Vicentina, 1976.

VOLDMAN, D. Definições e usos. In: FERREIRA, M. M.; AMADO, J. (Org.). Usos e abusos da História Oral. 5. ed. São Paulo: Fundação Getúlio Vargas, 2002, p. 33-41.

Recebido em agosto de 2010. Aprovado em agosto de 2010. 